Jul 11th, 8:50 AM - 9:10 AM

\title{
Application of a Comprehensive Integrated Assessment Tool for the Brussels Capital Region
}

Peter Viaene

VITO NV, peter.viaene@vito.be

Enrico Turrini

University of Brescia, enrico.turrini@ing.unibs.it

Claudio Carnevale

University of Brescia, claudio.carnevale@ing.unibs.it

Marialuisa Volta

University of Brescia, marialuisa.volta@ing.unibs.it

Roberta Gianfreda

TerrAriasrl,r.gianfreda@terraria.com

See next page for additional authors

Follow this and additional works at: https://scholarsarchive.byu.edu/iemssconference

Part of the Civil Engineering Commons, Data Storage Systems Commons, Environmental Engineering Commons, Hydraulic Engineering Commons, and the Other Civil and Environmental Engineering Commons

Viaene, Peter; Turrini, Enrico; Carnevale, Claudio; Volta, Marialuisa; Gianfreda, Roberta; Maffeis, Guiseppe; Declerck, Priscilla; Brasseur, Olivier; and Valkering, Pieter, "Application of a Comprehensive Integrated Assessment Tool for the Brussels Capital Region" (2016). International Congress on Environmental Modelling and Software. 35.

https://scholarsarchive.byu.edu/iemssconference/2016/Stream-A/35

This Event is brought to you for free and open access by the Civil and Environmental Engineering at BYU ScholarsArchive. It has been accepted for inclusion in International Congress on Environmental Modelling and Software by an authorized administrator of BYU ScholarsArchive. For more information, please contact scholarsarchive@byu.edu, ellen_amatangelo@byu.edu. 


\section{Presenter/Author Information}

Peter Viaene, Enrico Turrini, Claudio Carnevale, Marialuisa Volta, Roberta Gianfreda, Guiseppe Maffeis, Priscilla Declerck, Olivier Brasseur, and Pieter Valkering 


\title{
Application of a Comprehensive Integrated Assessment Tool for the Brussels Capital Region
}

\author{
Peter Viaene $^{a}$, Enrico Turrini ${ }^{b}$, Claudio Carnevale ${ }^{b}$, Marialuisa Volta $^{b}$, Roberta Gianfreda $^{c}$, \\ Guiseppe Maffeis $^{c}$, Priscilla Declerck ${ }^{\mathrm{d}}$, Olivier Brasseur ${ }^{\mathrm{d}}$, Pieter Valkering ${ }^{\mathrm{a}}$ \\ a VITO NV, Boeretang 200, 2400 Mol, Belgium (peter.viaene, pieter.valkering@vito.be) \\ ${ }^{\mathrm{b}}$ Department of Mechanical and Industrial Engineering, University of Brescia, 25123 Brescia, Italy \\ (enrico.turrini, claudio.carnevale, marialuisa.volta@ing.unibs.it) \\ c TerrAria srl, via M. Gioia 13220125 Milan, Italy (r.gianfreda, g.maffeis@terraria.com) \\ ${ }^{\mathrm{d}}$ Bruxelles Environnement, Avenue du Port 86C/3000, 1000 Bruxelles, Belgium \\ (pdeclerck, obrasseur@environnement.irisnet.be)
}

\begin{abstract}
While in general air quality has improved in Europe over the past decades, there are still problems with exceedances of ambient air quality limit values in many urban areas. To design efficient Air Quality Plans to face these problems, methodologies and tools are required to assess the effects of possible abatement measures on local air quality. One such tool is RIAT+ (www.riatplus.eu). In this contribution to IEMSs, we'll present an application of the RIAT+ tool to the Brussels Capital Region (BCR). Specific challenges for this application are the limited area of the BCR and the constraint that only emission abatement measures that were deemed politically viable could be considered. The emission abatement measures available to the Brussels Environmental Agency will be presented and discussed. RIAT+ efficiently calculates air concentrations from emissions using an artificial neural network as a source/receptor model. Input for this source/receptor model was obtained from the results of a validated AURORA chemical transport model setup for the BCR. Once the receptor model was validated, RIAT+ was then used to calculate the effect of the different proposed abatement measures on air quality. We'll discuss both the results obtained using RIAT+ as well as the lessons learned from this particular case study.
\end{abstract}

